Grocott, J. 1981: Structural evolution of the Ikerasak area, Umanak district, central West Greenland. Rapp. Grønlands geol. Unders. 105 (this volume).

Korstgård, J. A. (edit.) 1979: Nagssugtoqidian geology. Rapp. Grønlands geol. Unders. 89, 146 pp.

Pulvertaft, T. C. R. 1973: Recumbent folding and flat-lying structure in the Precambrian of northern West Greenland. Phil. Trans. R. Soc. Lond. A 273, 535-545.

Pulvertaft, T. C. R. 1.979: Mapping in the Umanak district, central West Greenland. Rapp. Grønlands geol. Unders. 95, 27-30.

Institut for almen Geologi, $\emptyset$ ster Voldgade 10 DK-1350 Copenhagen $K$

\title{
Coal in West Greenland
}

\section{S. Chandra Shekhar, N. Frandsen and E. Thomsen}

The 1980 summer field season for the 'Coal Project' (Frandsen \& Shekhar, 1980) began about the first week of April. Longyear Canada Inc. carried out the drilling on Nûgssuaq, and Greenex A/S were the management consultants. Eighteen profiles were measured in the Atâ-Pautût region and another profile was measured in the Kingigtoq area. Eight slit samples of selected coal seams were taken for analysis.

\section{Fossiliferous sequence at Atâta kûa}

Several sections were measured on the north side of the valley Atâta kûa (fig. 13). These were all sections of the ordinary coal-bearing sequence except for the westernmost section (location 11, fig. 13). The sediments of this section have a west-north-westerly dip of $10^{\circ}$ in contrast to the almost horizontal coal-bearing sediments of the area, and the total measured thickness of the sediments, which are black to brownish shale, is $74 \mathrm{~m}$. Intercalated in the shale are four zones between $0.4 \mathrm{~m}$ and $1.9 \mathrm{~m}$ thick. The zones are either continuous bands or long, flat lenses of very coarse to pebbly sandstone interbedded with dark grey shale, individual beds having a thickness between a few millimetres and a few centimetres. The sandstone beds have a very hard, dark brown matrix and some contain abundant molluscs while some of the shale beds contain well preserved leaf impressions.

The lower half of the section contains scattered lenticular concretions. The concretions are dark brown and very hard, $20-30 \mathrm{~cm}$ thick and up to $1 \mathrm{~m}$ long.

The shale is underlain by a badly exposed, very coarse conglomerate with boulders up to 1 $\mathrm{m}$. The boulders are sedimentary rocks in a matrix of coarse sandstone with rounded quartzite pebbles.

More work on the fossils of this section is required before an interpretation of age and depositional environment is possible, but tentatively it is suggested that the sediments can be correlated with the marine rocks of the Danian Kangilia or Agatdal Formations (Rosenkrantz, 1970). 
Fig. 13. Southern part of the Nûgssuaq peninsula. Dots indicate surface sections measured and described during the present coal investigations. Stars indicate locations of boreholes drilled in 1980 .

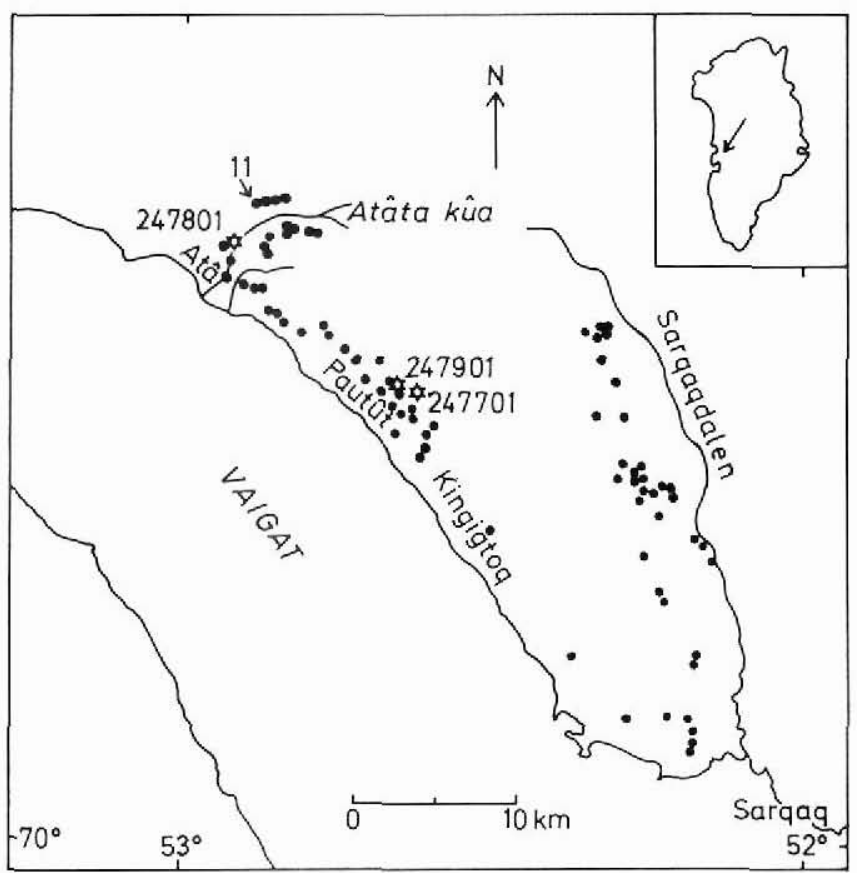

\section{Drilling 1980}

It was planned to drill up to $3000 \mathrm{~m}$ in up to six boreholes during the 1980 field season. However, only a total of $1087 \mathrm{~m}$ were drilled during the season (including drilling in abandoned boreholes) but valuable data and experience have been gained which can be used for future exploration of the area.

Drilling at Nûgssuaq was carried out using a Longyear '44' drilling rig and cores of $\mathrm{HQ}$ $(63.5 \mathrm{~mm}), \mathrm{NQ}(47.6 \mathrm{~mm})$ and $\mathrm{BQ}(36.5 \mathrm{~mm})$ dimensions were recovered. The 'Q' series wire-line equipment was used throughout. The drilling fluid was a mixture of water, calcium chloride and zeogel mud. Calcium chloride was used because of suspected permafrost in the area and to avoid freezing of the drilling equipment in the borehole. Zeogel mud (a viscosifier) was used to facilitate the recovery of rock cuttings and caving materials from the borehole. The choice of mud was very limited due to the use of calcium chloride. Conventional filtrate muds like Bentonite (filtrate cake/wall building material) could not be used.

Drilling through porous and friable sandstones resulted in lost circulation of the drilling fluid and this made drilling difficult. The rock cuttings, together with the material caving into the borehole, could not be washed out and this material often jammed the drill string. Also thin swelling clay bands and suspected cavities within the rock formation posed drilling problems. Plugging of lost circulation zones using permafrost cement and 'Kwikseal' was successful, but very time-consuming. Boreholes 247901 and 247801 (first location) (fig. 13) had to be abandoned at depths of $175 \mathrm{~m}$ and $103 \mathrm{~m}$, respectively, due to the above mentioned problems. 
Table 3. Details on coal seams encountered in boreholes

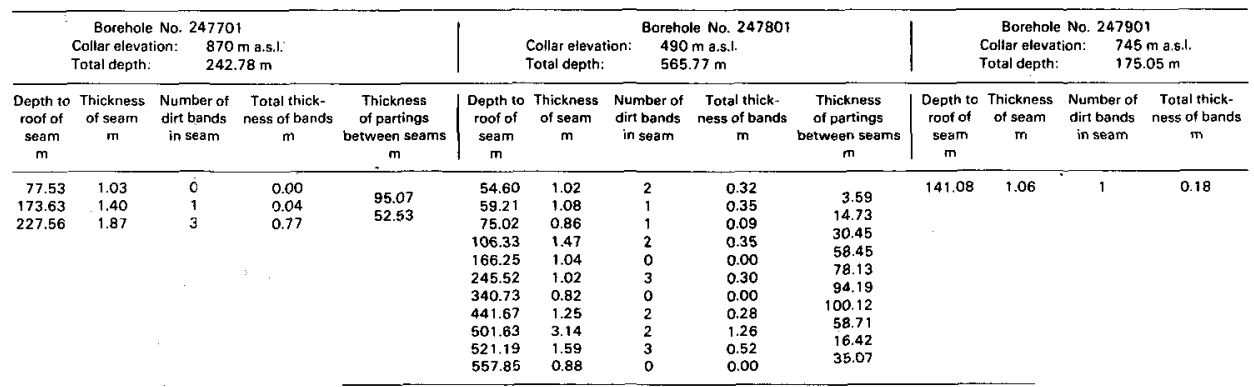

At a second location of borehole 247801 it was decided to telescopically reduce the borehole to smaller diameters at difficult horizons, starting with drilling in HQ dimension below the overburden. The borehole was successfully drilled down to $566 \mathrm{~m}$, the bottom 198 $\mathrm{m}$ being drilled in $\mathrm{BQ}$ dimension.

Borehole 247701 was drilled down to $243 \mathrm{~m}$ where drilling had to be given up due to problems encountered with very soft pebbly sandstones and also deteriorating weather conditions.

Core recoveries in coal and non-coal rocks were good in all the boreholes. The averange core recovery in coal seams is more than $95 \%$, in shales about $90 \%$ and in sandstones about $85 \%$. The coal seams encountered in the boreholes appear to be slightly better in quality than the coal observed in the surface exposures.

The mineable coal seams ( $>0.8 \mathrm{~m}$ thick) encountered in the various boreholes are shown in Table 3.

\section{Petrophysical logging}

'Down the hole' logging of boreholes has been very satisfactory even though logging was done through the rods. The coal combination sonde (CCS), comprising caliper log, gamma log, bed resolution density and long spacing density logs, has been a very useful tool in cross-checking the coal seam depths (from the gamma ray and density curves) wherever the core recoveries have not been $100 \%$. Due to the friable nature of the rock and unstable side-wall conditions in the borehole, open-hole logging was not attempted in borehole 247901 and 247801 . The neutron sonde was not very useful in delineating coal seams.

\section{Laboratory analyses}

Analyses of 27 slit samples of coal seams collected during the 1979 field season have been undertaken by Bergbau Forschung, Essen. The quality of the coal seams varies greatly. The comparatively better quality seams have a range of moisture content between $8.0 \%$ and $12.9 \%$, ash content between $11.1 \%$ and $33.3 \%$ (on dry basis), volatile matter between $31.8 \%$ and $43 \%$ (on dry basis), and gross calorific value between $3687 \mathrm{kcal} / \mathrm{kg}$ and 5421 $\mathrm{kcal} / \mathrm{kg}$. 
The results of maceral group analysis and rank determination under the microscope have also been obtained for five coal samples. The samples are very rich in vitrinite and poor in inertinite. The content of separated minerals at a density of $1.9 \mathrm{~g} / \mathrm{ml}$ is high. The rank determinations were made by measuring the averange reflectance on vitrinites. The range of reflectance values is between $0.42 \%$ and $0.49 \% R_{\mathrm{m}}$.

The preliminary chemical analyses and petrographic studies suggest that the coal of Nûgssuaq is of low rank, high volatile, bituminous $C$ variety.

\section{References}

Frandsen, N. \& Shekhar, S. C. 1980: Coal in West Greenland. Rapp. Grønlands geol. Unders. 100, 49-51.

Rosenkrantz, A. 1970: Marine Upper Cretaceous and lowermost Tertiary deposits in West Greenland. Meddr dansk geol. Foren. 19, 406-453.

\section{Chromium-rich sapphirine from the Bjørnesund area, southern West Greenland and its bearing on the conditions of crystallisation of the Fiskenæsset anorthosite complex}

\section{R. L. Friend and D. J. Hughes}

Windley et al. (1973) have postulated that the Fiskenæsset anorthosite complex crystallised under conditions of high water vapour pressure. This hypothesis readily explains several of the distinct characteristics of the complex. In particular, the late precipitation of chromitite layers towards the top of the complex in the anorthosite sensu stricto (Ghisler \& Windley, 1967) is not normally expected in large layered intrusions (Wager \& Brown, 1968), and is explained because the early precipitation of chromite is suppressed under such conditions (Shiraki, 1966). Also, Windley et al. (1973) have suggested that chromium amphibole, rather than pyroxene, was precipitated in association with the chromite as a direct consequence of the enrichment of volatiles in the upper parts of the intrusion.

During the mineralogical investigation of samples collected from a site north of Bjørnesund (Fig. 14), at the intrusive, upper contact of the Fiskenæsset anorthosite complex with supracrustal rocks which contain aluminous ultramafic bodies (Friend \& Hughes, 1977), evidence has come to light which directly supports the elevated water vapour pressure hypothesis.

At this locality, where the aluminous ultramafic rocks are in contact with and engulfed by the intrusive anorthosite, a reaction has occurred to give an extensive development of the Mg-Al-rich minerals sapphirine and kornerupine. The sample GGU 149434 was selected for investigation because it contains purple and maroon colour-zoned sapphirine, with 